\title{
Requisite Intellect Needed in Africa's Animal Husbandry to Increase Productivity
}

\author{
Mbassa GK* \\ Department of Anatomy and Pathology, St. Francis University College of Health and Allied Sciences Tanzania
}

*Corresponding author: Mbassa GK, Department of Anatomy and Pathology, St. Francis University College of Health and Allied Sciences Tanzania
Received Date: February 06, 2020

Published Date: February 13, 2020

\section{Opinion}

The world human population at 7.6 billion in 2020 is projected at $8.6 \mathrm{~b}$ in $2030,9.8 \mathrm{~b}$ in 2050 , increasing by $33 \%$ in least developed countries (UN Report 2017). Populations of 26 African countries will double, with Nigeria, Democratic Republic of Congo, Ethiopia, Tanzania and Uganda being forefront, thus efficiency in agriculture is essential. Food production has increased worldwide but $50 \%$ of Africans do not get adequate amounts, even essentials like milk. In 2014 world milk production was 933,976 tons ( $\mathrm{t}$ ) condensed, 3,597,015t dried and 2,601,076t evaporated, Africa contributed only $1.5 \% \quad(13,826 \mathrm{t}), \quad 1.4 \% \quad(48,564 t)$ and $0.8 \% \quad(19,776 \mathrm{t})$ respectively FAO [1] despite having $23.2 \%(346,475,266)$ of 2017 world's 1,491,687,240 cattle. This low milk production trend in Africa notifies that Sustainable Development Goals 1 to end poverty and 2 to end hunger will not be achieved by 2030 and most likely all the 17 goals. This paper gives opinion on pathways to increase animal productivity.

\section{Livestock Farming Challenges in Africa}

Livestock farming in Africa is affected by many factors centred on inputs; capital, land, technology, animal breeds, management, workforce, intellect, interest, feeds and feeding processor, water, pastures \& fodder, fertilizers, tools, health plans, medicines, vaccines, pesticides, medicators, machinery, product processors, policies, markets and law compliance Njonge [2], Asizua [3]. Pastoralism and agro-pastoralism (APP), the dominant farming systems Ndambi [4], Guadu and Mangistie [5], FAO [6] constitutes 90\% of dairy ruminant population. In Tanzania $94 \%$ of livestock population are under APP (URT, Min. Liv. \& Fish. Dev. Report 2019), 6\% are under smallholders and large farms. Cattle under APP yield 0.5-1 litre (L)/ animal/day Kurwijira \& Henricksen [7] thus the country produces 54.8 million Litres milk/annum. Dairy farms with cross-and pure breeds produce $2-5 \%$ of milk on market, $95-98 \%$ share filled by imports. Annual per capita milk consumption is 47L, against $200 \mathrm{~L}$ world level. Generally, in Africa genetic improvement has not been widely implemented to transform beef and dairy production Opoola [8], Ojango [9]. Livestock farming receives inadequate government support on capital, technology and markets. Animals are of low productivity genes. Genetically high producer exotic breeds, their infrastructure, housing, health, technology and management needs are unaffordable by ordinary families. Diseases of animals include parasites, fungi, protozoa, ehlichia, virus and bacteria. Qualitative and quantitative deficiencies in animal feeds are most significant Mbwambo [10]. Markets for live animals, milk, meats and products are highly unreliable, making livestock farming risky, thus left for illiterate poor communities with no other income sources, who rear animals on APP on general lands without investing anything (low input low output), unable to produce adequate milk, export meat, leather \& leather goods. Therefore, APP is claimed to be economical in arid and semiarid lands Bollig [11], however, human population growth has severely constrained unrestricted grazing. Strong cultural bonds in some pastoralists force them to segregate themselves from country governance, development and modern farming, wanting to be left alone, gaining sympathies from some groups Mattee \& Shem [12], Tenga [13], Mgongo [14], Galvin [15], and this complicates the transformation from APP to modern profitable farming. Sustained unrestricted pastoralism, however, is causing many fatal land conflicts between pastoralists, and crop farmers, forests \& wildlife areas, urban \& villages Le Meur [16] , Kushoka [17], James [18], Massoi [19], Mbonde [20], Mwambashi [21], Massay [22]. Vision is lacking on scenarios of grazing in general land without investing to regenerate feeds and water. Seeking for solid practical information on modernizing livestock farming in Africa is, therefore, inevitable. 


\section{Pathways to Enhancing Livestock Productivity in Africa}

Sudan, Kenya, South Africa, Egypt, Morocco, Algeria and Ethiopia are reported to have enhanced milk production Louw [23] but many countries have not. It is highly unlikely that Africa will achieve SDG1 and SDG2 within next decade, unless radical strategic livestock farming modernization plans are set and implemented. Livestock productivity in APP system is too low to adequately supply growing human populations and, the land is also shrinking because of increasing users. In order to sustainably ascend beyond APP, modernizing livestock farming is necessary, achievable by raising intelligence to generate people interested in farming. Many African countries have plenty of arable land to produce feeds and water using available efficient modern technologies. Fights over land and water are due to unwillingness of people to think, plan, invest and work their plans; instead they opt for minimal intelligence, and follow inherited living styles from ancestors, who did not have knowledge and technology.

Increasing productivity oflivestock production in Africa requires strong investment, infrastructure, innovations FAO [24]. The factors steering shift from APP to modern farming are population growth (need food), climate change, decreasing free grazing land, expanding milk, meat and products markets, Africa's realization of self-development, widening university education, growing middle-income earners, increasing demands for high quality foods, raising security, safety, health, quality life, living standards, better technology, markets, good animal breeding and disease control technologies, easing management by farm automation, digital knowledge, artificial intelligence and use of drones and networking. The two binding actors in modernizing livestock farming are people and governments [25]. People must modernize themselves, move out of past cultures and venture into high-value production. Governments must identify people interested to invest in livestock production, give them loans and grants; young university graduates (Namibian model), young changing APPs and others. Governments should develop markets, create export opportunities, connect farms and markets, and utilize opportunities in digital technologies and artificial intelligence. Governments should ensure that all children born have homes, none should wander in jungles following animals.

\section{Acknowledgment}

None.

\section{Conflicts of Interest}

No conflicts of Interest.

\section{References}

1. FAO (2019) Developing sustainable value chains for small-scale livestock producers. Edited by G. Leroy \& M. Fernando. FAO animal production \& health guidelines no. 21. Rome.

2. Njoge FK (2017) Challenges faced by smallholder dairy farmers in Kirinyaga County, Kenya. IOSR J Agric Vet Sci 10(8): 71-75.
3. Asizua D, Mpairwe D, Kabi F, Mutetikka D, Hvelplund T, et al. (2017) Effects of grazing \& feedlot finishing duration on performance of three beef cattle genotypes in Uganda. Liv Sci 99: 25-30.

4. Ndambi,O A, Hemme T, Latacz-Lohmann U (2007) Dairying in Africa: Status \& recent dev. Liv. Res. Rur. Dev 19(8): 1-3.

5. Guadu T, Mangistie A (2016) Challenges, opportunities and prospects of dairy farming in Ethiopia: A Review. World Journal of Dairy \& Food Sciences 11: 1-9.

6. FAO (2019) Resilience analysis of pastoral and agro-pastoral communities in South Sudan's cross-border areas with Sudan, Ethiopia, Kenya and Uganda. Rome. 28 pp. License: CC BY-NC-SA 3.0 IGO.

7. Kurwijira RL, Henricksen J (1994) Milk supply to urban centres in Tanzania with particular reference to the city of Dar es Salaam.

8. Opoola O, Mrode R, Banos G, Ojango J, Banga C, et al. (2019) Current situations of animal data recording, dairy improvement infrastructure, human capacity and strategic issues affecting dairy production in subSaharan Africa. Trop Anim Hlth Prod 51: 1699-1705.

9. Ojango JMK, Mrode R, Okeyo AM, Rege JEO, Chagunda MGG, et al. (2017) Improving smallholder dairy farming in Africa. Burleigh Dodds Science Publishing Limited, pp. 1-26.

10. Mbwambo N, Nandonde S, Ndomba C, Desta S (2016) Assessment of animal feed resources in Tanzania, Bill and Melinda Gates Found. Min. Liv. \& Fish. Dev. Tanzania. ILRI Nairobi Kenya. ISBN:92-9146-512-7, p. 24

11. Bollig M, Schnegg M, Hans-Peter Wotzka (2014) Pastoralism in Africa: Past, Present \& Future (A Review). Afr Stud Rev 57: 201-203.

12. Mattee AZ, Shem M (2006) Ambivalence and contradiction: A review of policy environment in Tanzania in relation to pastoralism. IIED Issue Pap. No 140, London. Intern Inst Env Dev p. 113

13. Tenga R, Mattee A, Mdoe N, Mnenwa R, Mvungi S, et al. (2008) A study on options for pastoralists to secure their livelihoods in Tanzania; Current policy, legal and economic issues, Volume One: Main Report. Published by CORDS, PWC, IIED, MMM Ngaramtoni Centre, TNRF and UCRT, funded by CORDAID, TROCAIRE, Ireland Aid and the Wildlife Conservation Society AHEAD Programme. pp. 113.

14. Mgongo FOK, Matiko MK, Batamuzi EK, Wambura RM, Karimuribo ED, et al. (2014) Pastoral indigenous breeding practices and their impact on cattle reproduction performance: case of Kilosa \& Gairo. Liv Res Rural Dev 26(4).

15. Galvin KA, Beeton TA, Boone RB, Burn Silver SB (2015) Nutritional Status of Maasai Pastoralists under Change Hum Ecol Interdiscip J 43(3): 411-424.

16. Le Meur P, Hochet P, Shem M, Touré O (2006) Conflict over access to land and water resources within Sub-Saharan Dry Lands; Underlying factors, conflict dynamics and settlement processes. GRET-FAO LEAD Final Report, Groupe de recherche et d'échanges technologiques, France.

17. Kushoka NA (2011) Land use plan and farmers-pastoralists conflict in Mvomero District: it's implications on household food production. Dissertation: MA, Sokoine Univ. Agric. Morogoro, Tanzania, p. 54.

18. James $H$ (2015) Analysis of pastoral and farmers land conflict in Tanzania: case study of Arumeru. Dissertation; MSc. Mzumbe University. Tanzania, pp. 72 .

19. Massoi LW (2015) Land conflicts \& livelihood of pastoral Maasai women in Kilosa Tz. Afr Foc 28: 107-120.

20. Mbonde FJ (2015) Assessment of land use conflicts in Tanzania: Case study of Songambele and Mkoka villages, Kongwa distr, Dodoma region. Dissertation: MSc. Mzumbe Univ. Tanzania, p. 73.

21. Mwambashi ER (2015) Assessing the impact of land conflict between farmers and pastoralists in Tanzania: Case of Ulanga. Dissertation: MPA Mzumbe Univ Tz, p. 89. 
22. Massay GE (2017) In search of the solution to farmer-pastoralist conflicts in Tanzania. Tanzania Natural Resource Forum. South Afr. Inst. Internat. Affairs. Occasional Pap 257: 1-17.

23. Louw JMA (2013) Challenges of Dairy Industry in Southern Africa. Res. Report MBA, Univ. Stellenbosch.
24. FAO (2016) Family Farming Knowledge Platform: Problems and Prospects of Dairy farming in Central Region of Eritrea, East Africa Intern. J Man Soc Sci 4(5).

25. Mwasha DI (2016) Farmer-pastoralist conflict in Kilosa district, Tanzania: Climate change orientation. MA Sokoine (Ed.), Dissertation. Univ Agric Tz p. 59. 